\title{
Can A Simple Complete Blood Count Predict Gestational Diabetes Mellitus?
}

\section{Basit Bir Tam Kan Sayımı Gestastonel Diyabetes Mellitusu Öngörebilir Mi?}

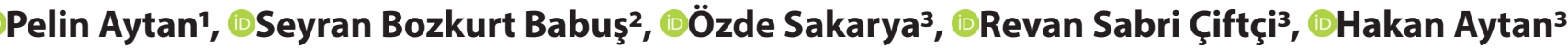 \\ 'Mersin University School of Medicine Department of Internal Medicine, Division of Hematology, Mersin, Turkey \\ ${ }^{2}$ Mersin University School of Medicine Department of Emergency Medicine, Mersin, Turkey \\ ${ }^{3}$ Mersin University School of Medicine Department of Obstetrics and Gynecology, Mersin, Turkey
}

\begin{abstract}
Aim: To assess the role of simple complete blood count $(C B C)$ in prediction of gestational diabetes (GDM).

Material and Method: Pregnant women screened for GDM in 24-28 gestational weeks with a 75g-OGTT between January 2018-January 2020 were retrospectively investigated. Patients with a known systemic disease, using aspirin, low-molecular-weight heparin and steroids were excluded. A total of 359 patients (81 with GDM and 278 controls) were enrolled. The assessed parameters in $C B C$ were hemoglobin, hematocrit, red blood cells, mean corpuscular volume, mean corpuscular hemoglobin concentration, white blood cells (including neutrophils, lymphocytes, monocytes, eosinophils, basophils), platelets, platelet distribution width (PDW), mean platelet volume (MPV), red cell distribution width (RDW), nucleated red blood cell (NRBC), NRBC percentage, plateletcrit $(\mathrm{PCT})$, platelet large cell ratio (P-LCR), immature granulocytes (IG) and IG percentage. Platelet mass index (PMI), neutrophil-tolymphocyte ratios (NLR) and platelet-to-lymphocyte ratios (PLR) were calculated. These parameters were compared between GDM patients and controls. Regression analysis was performed with the parameters that were significantly correlated with GDM. ROC curve analysis was done in order to find cut-off values.

Results: RBC, WBC (all subtypes including immature granulocytes), platelet indices including PMI, NLR and PLR were all similar. Only RDW and NRBC were found to be significantly increased in GDM patients and came out to be independent predictors of GDM with maternal age and screening week.

Conclusion: These findings suggest that women with GDM may be accompanied with increased RDW and NRBC levels which seem to be independent predictors of this disease and these parameters may be used to monitor and evaluate the development of GDM.

Keywords: Gestational diabetes mellitus, nucleated red blood cell, red cell distribution width, platelet indices, complete blood count
\end{abstract}

\section{Öz}

Amaç: Basit bir tam kan sayımının (TKS) gestasyonel diyabetus mellitus (GDM) öngörüsündeki rolünü değerlendirmek

Gereç ve Yöntem: Ocak 2018-Ocak 2020 yılları arasında 24-28. Gebelik haftalarında $75 \mathrm{~g}$ oral glukoz tolerans testi ile GDM taraması yapılan gebeler retrospektif olarak değerlendirildi. Bilinen sistemik hastalığı olan, aspirin, düşük-molekül-ağılıklı heparin veya steroid kullanan hastalar elendi. Toplam 359 hasta (81 GDM'li ve 278 kontrol) çalışmaya alındı. TKS içinde hemoglobin, hematokrit, eritrositler, ortalama korpüsküler hacim ve hemoglobin konsantrasyonu, lökositler (nötrofil, lenfosit, bazofil, monosit, eozinofil dahil), trombositler, trombosit dağılım genişliği, ortalama trombosit hacmi, kırmızı-hücre dağıım genişliği (RDW), çekirdekli kirmizi kan hücreleri (ÇKKH) ve yüzdesi, plateletkrit, trombosit büyük hücre oranı ve immatür granülosit ve yüzdesi mevcuttu. Trombosit kütle indeksi (TKI), nötrofil-lenfosit (NLO) ve trombosit-lenfosit oranları (TLO) hesaplandı. Bu parametreler GDM olan ve olmayan hastalarda karşılaştırıldı. GDM ile anlamlı korelasyon gösteren parametrelerle regresyon analizi yapıldı. Eşik değer hesaplaması ROC eğrisi analizi ile yapıldı.

Bulgular: Eritrositler, lökositler (immatür granülosit dahil tüm alt gruplar), TKI, NLO ve TLO da dahil trombosit indeksleri gruplarda benzerdi. Sadece RDW ve ÇKKH, GDM'li hastalarda anlamlı olarak yüksek olarak bulundu ve bu parametreler yaş ve tarama haftası ile birlikte GDM için bağımsız prediktörler olarak tespit edildi.

Sonuç: Bu sonuçlar GDM'li hastalarda RDW ve ÇKKH seviyelerinin artmış olduğunu, bu parametrelerin GDM için bağımsız prediktörler olarak görüldüğünü ve GDM gelişmesinin izleminde ve değerlendirilmesinde kullanılabileceğini göstermektedir.

Anahtar Kelimeler: Gestasyonel diabetes mellitus, çekirdekli kırmızı kan hücreleri, kırmızı hücre dağılım genişliği, tromosit indeksleri, tam kan sayımı

Corresponding (illetişim): Pelin Aytan, Mersin University School of Medicine Department of Internal Medicine, Division of Hematology, Mersin, Turkey

E-mail (E-posta): drpelinaytan@gmail.com

Received (Geliş Tarihi): 20.09.2020 Accepted (Kabul Tarihi): 23.09.2020 


\section{INTRODUCTION}

Diabetes mellitus is the most common medical disorder complicating pregnancy with about a prevalence of $10 \%$ and gestational diabetes mellitus (GDM) represents $90 \%$ of these cases. ${ }^{[1]}$ GDM results from carbohydrate intolerance that develops due to placental hormones that peak in the late second trimester. Insulin resistance and chronic subclinical inflammation are suggested to be the underlying mechanisms of the disease. ${ }^{[2]}$ It is observed that the frequency of GDM is increasing and GDM continues to represent a significant challenge for both clinicians and investigators as it may cause maternal and fetal complications if not managed appropriately. Therefore, diagnosis is important and all pregnant women are recommended to be screened for GDM with a laboratory-based screening test using blood glucose levels. ${ }^{[3,4]}$

Screening may either be done with using a 75-g, 2-hour oral glucose tolerance test (OGTT) or using a-two-step approach starting with a 50-g OGTT and continue with a 100-g, 3-hour diagnostic OGTT if the result is above the cut-off values. However, not infrequent, some women cannot tolerate to drink such a liquid containing that much glucose with at least 8-hour fasting time. And unfortunately, there is still no practical way to predict GDM before screening tests.

This has led investigators to find alternative screening modalities. Measurement of hemoglobin A1c has been proposed however, due to its decreased sensitivity compared with OGTT, it is not found to be suitable for use alone. ${ }^{[5]}$ Some investigators focused on the inflammatory markers as there is chronic low-grade inflammation that triggers vascular injury and dysfunction and subsequent platelet activation in GDM. ${ }^{[6,7]}$ Recently because, systemic inflammatory response markers that are components of complete blood count test (CBC) including neutrophilto-lymphocyte ratio (NLR) and platelet-to- lymphocyte ratio $(\mathrm{PLR}){ }^{[8-10]}$ platelet indices including platelet count, mean platelet volume (MPV) platelet distribution width (PDW), plateletcrit $(P C T),{ }^{[11,12]}$ white blood cells, red blood cells ${ }^{[13]}$ are suggested to differ in GDM patients in different studies. However, in some other studies these results could not be confirmed. ${ }^{[10,14-17]}$

$\mathrm{CBC}$ is a convenient and inexpensive test that provides important information. In addition to the above parameters that had been assessed in GDM, immature granulocytes, platelet mass (platelet count $x$ MPV/1000), nucleated red blood cells (NRBC) and red cell distribution width (RDW) are also components of $\mathrm{CBC}$ that have been correlated with inflammation and blood glucose. ${ }^{[18,19]}$ There is scarce data with regard to the correlation of these components of the CBC with GDM. And in light of the inconsistent findings the aim of this study was to assess the role of simple CBC in prediction of GDM.

\section{MATERIALS AND METHODS}

All the pregnant women who were screened for GDM in their 24-28 gestational weeks with a $75 \mathrm{~g}$ OGTT in our obstetrics department between January 2018 and January 2020 were included in this retrospective cohort study. All the data were obtained from the electronic data base of the hospital. Screening is offered to all pregnant women in our clinic between 24-28 gestational weeks unless she has risk factors for earlier testing ${ }^{[3]}$ For standardization, patients with a known systemic disease that would cause inflammatory changes and interfere with $C B C$ results, such as hypertension, preeclampsia, renal failure, cardiac diseases, thyroid abnormalities, rheumatologic disorders, any kind of autoimmune diseases, malignancies and respiratory diseases were excluded. Women who were using aspirin, low molecular weight heparin and steroids for any reason were also excluded. In addition, only the patients to whom a CBC was ordered at the same time during GDM screening were included. The institutional ethics approval was obtained for the study.

The screening for GDM using a 75-g, 2-hour OGTT had been performed as follows: the woman was recommended not to eat or drink for 8 to 14 hours before the test and was instructed to drink a standard liquid that contains $75 \mathrm{~g}$ glucose after her blood was drawn. Every 60 minutes after she drank the liquid, blood was drawn again for two more times. She was not allowed to eat or drink during the test. The diagnosis of GDM be established when any single threshold value was met or exceeded (fasting value, $92 \mathrm{mg} / \mathrm{dL}$; 1 -hour value, $180 \mathrm{mg} / \mathrm{dL}$; or 2-hour value, $153 \mathrm{mg} / \mathrm{dL}$ ). ${ }^{[20]}$

The blood sample for $C B C$ is drawn before the patient is asked to drink the standard liquid. The CBC was analyzed by with the SYSMEX-XN-1000/23797 hemogram device. The assessed parameters in CBC were hemoglobin, hematocrit, red blood cells, mean corpuscular volume (MCV), $\mathrm{MCH}$ concentration, white blood cells (including neutrophils, lymphocytes, monocytes, eosinophils, basophils, and their percentages), platelets, PDW, $M P V$, RDW, NRBC, NRBC percentage, $P C T$, platelet large cell ratio (P-LCR), immature granulocytes (IG) and IG percentage. Platelet mass index (PMI) was calculated by multiplying platelet number with MPV and divide the result by 1000 . NLR and PLR are calculated by dividing the absolute neutrophil and platelet counts by the absolute lymphocyte count.

Statistical analysis was accomplished with statistical program for social sciences (SPSS 22, demo version, IBM). Normality of the data was tested with Kolmogorov-Smirnov Test. Normally distributed data were expressed as mean \pm standard deviation and compared with $\mathrm{t}$ test. Mann-Whitney $\mathrm{U}$ test was used for comparison of non-normally distributed data which were expressed as median (interquartile range). Binomial data were expressed as percentages and compared with chi square test. Correlation analysis (Pearson or Spearman coefficients where appropriate) was done to find factors that had correlations with diagnosis of GDM and a regression analysis was performed with these factors that were found to have significant correlation in order to find out the independent predictors of GDM diagnosis. ROC curves were constructed for independent predictors of GDM diagnosis to establish diagnostic cut-off values. A value of $\leq 0.05$ was considered to be significant. 


\section{RESULTS}

A total of 756 patients had been screened for GDM with a 75-g OGTT and 359 pregnant women fulfilled the inclusion criteria. Eighty-one of these 359 patients were diagnosed to have GDM (22.6\%). The demographic characteristics of the patients are depicted in Table 1. The patients with GDM were significantly older, had screening one week later and had fetuses with lower 1 and 5 minutes-APGAR scores than the control patients (Table 1).

The comparison of complete blood count parameters is shown in Table 2. Hematocrit, RDW, PCT and NRBC were all significantly higher in the GDM patients. In the GDM patients and the controls PLR (135.2 \pm 41.1 vs $132.2 \pm 49.1$, p:0.610, respectively), NLR (4.1 \pm 1.2 vs $4.1 \pm 1.8$, p:0.776, respectively) and PMI (2655.8 \pm 637.8 vs $2553.8 \pm 536.8, \mathrm{p}: 0.151$, respectively) did not differ significantly. Correlation analysis showed that GDM was positively correlated with age, screening week, gravidity, hematocrit, RDW, PCT and

\begin{tabular}{|c|c|c|c|}
\hline & Controls & GDM patients & $\mathbf{p}$ \\
\hline Age (years) & $30.4 \pm 5.2$ & $34.9 \pm 5.7$ & $<0.0001$ \\
\hline Gravidity & $2.3 \pm 1.6$ & $2.7 \pm 1.5$ & 0.06 \\
\hline Screening week & $25.5 \pm 1.6$ & $26.5 \pm 2.3$ & $<0.0001$ \\
\hline Gestational week at delivery & $38.0 \pm 1.6$ & $37.4 \pm 2.4$ & 0.039 \\
\hline Fetal birthweight (grams) & $3242.9 \pm 513$ & $3172.5 \pm 705$ & 0.418 \\
\hline Umbilical cord blood pH & $7.3 \pm 0.1$ & $7.2 \pm 1.0$ & 0.274 \\
\hline AGGAR 1 minute & $7.9 \pm 1.2$ & $7.5 \pm 1.0$ & 0.029 \\
\hline APGAR 5 minutes & $9.2 \pm 0.9$ & $8.8 \pm 1.1$ & 0.002 \\
\hline Newborn intensive care unit need & $14 \%$ & $38 \%$ & $<0.0001$ \\
\hline
\end{tabular}

Table 2. Demographic and laboratory data of the patients with gestational diabetes and the healthy controls. (shown as mean \pm standard deviation or median (interquartile range) where appropriate)

\begin{tabular}{|c|c|c|c|}
\hline & Controls & GDM patients & $\mathbf{p}$ \\
\hline Hemoglobin (g/dL) & $11.3 \pm 1$ & $11.5 \pm 1.2$ & 0.291 \\
\hline Hematocrit (\%) & $33.4 \pm 2.8$ & $34.2 \pm 3.2$ & 0.031 \\
\hline RDW & $13.7 \pm 1.6$ & $14.2 \pm 1.5$ & 0.02 \\
\hline White Blood Cells & $10.2 \pm 2.3$ & $10.5 \pm 2.4$ & 0.592 \\
\hline Neutrophils & $7.4 \pm 1.9$ & $7.7 \pm 2.1$ & 0.256 \\
\hline Lymphocytes & $2.0 \pm 1.2$ & $1.9 \pm 0.5$ & 0.482 \\
\hline Monocytes & $0.65 \pm 0.4$ & $0.64 \pm 0.2$ & 0.826 \\
\hline Eosinophils & $0.11(0.12)$ & $0.12(0.1)$ & 0.270 \\
\hline Basophils & $0.04(0.02)$ & $0.030(0.03)$ & 0.429 \\
\hline Platelets $\left(/ \mathrm{mm}^{3}\right)$ & $244,300 \pm 58900$ & $252,500 \pm 66,800$ & 0.286 \\
\hline Platelet Distribution Width & $12.6 \pm 2.9$ & $13.1 \pm 2.5$ & 0.224 \\
\hline Mean Platelet Volume & $10.6 \pm 0.9$ & $10.6 \pm 1.1$ & 0.791 \\
\hline PCT & $0.25(0.07)$ & $0.26(0.08)$ & 0.047 \\
\hline PLCR & $29.2(9.7)$ & $29.6(11.85)$ & 0.627 \\
\hline NRBC & $0(0)$ & $0(0.1)$ & $<0.0001$ \\
\hline NRBC percentage & $0(0)$ & $0(0.1)$ & $<0.0001$ \\
\hline Immature granulocytes & $0.08(0.09)$ & $0.08(0.1)$ & 0.982 \\
\hline $\begin{array}{l}\text { Immature granulocytes } \\
\text { percentage }\end{array}$ & $0.8(0.8)$ & $0.9(0.7)$ & 0.956 \\
\hline PLR & $132.2 \pm 49.1$ & $135.2 \pm 41.1$ & 0.610 \\
\hline NLR & $4.1 \pm 1.8$ & $4.1 \pm 1.2$ & 0.776 \\
\hline PMI & $2553.8 \pm 536.8$ & $2655.8 \pm 637.8$ & 0.151 \\
\hline
\end{tabular}

NRBC (Table 3). These correlated parameters were included in the regression analysis. Age, screening week, RDW and NRBC were found to be independent predictors of GDM (Table 4).

\begin{tabular}{lcc}
$\begin{array}{l}\text { Table 3. Correlation analysis of possible factors related with gestational } \\
\text { diabetes }\end{array}$ & p \\
\hline & Correlation Coefficient & $<0.0001$ \\
\hline Age (years) & 0.338 & $<0.0001$ \\
Screening week & 0.229 & 0.014 \\
Gravidity & $0.130 *$ & 0.031 \\
Hematocrit (\%) & 0.114 & 0.002 \\
RDW & $0.160^{*}$ & 0.047 \\
PCT & $0.106^{*}$ & $<0.0001$ \\
NRBC & $0.188^{*}$ & \\
\hline *:Spearman rho, & & \\
RDW: Red cell distribution width & &
\end{tabular}

Table 4. Regression analysis of factors independently associated with gestational diabetes

\begin{tabular}{lcccc} 
& $\boldsymbol{\beta}$ & $\mathbf{t}$ & $\mathbf{p}$ & $\mathbf{9 5 \%}$ Confidence Interval \\
\hline Age & 0.311 & 5.693 & $<0.0001$ & $0.015-0.031$ \\
Screening week & 0.213 & 4.255 & $<0.0001$ & $0.026-0.070$ \\
Gravidity & 0.008 & 0.150 & 0.881 & $-0.026-0.030$ \\
Hematocrit & 0.070 & 1.373 & 0.171 & $-0.004-0.025$ \\
RDW & 0.116 & 2.333 & 0.020 & $0.005-0.058$ \\
PCT & 0.086 & 1.721 & 0.086 & $-0.004-0.061$ \\
NRBC & 0.141 & 2.820 & 0.005 & $3.860-21.678$ \\
\hline RDW: Red cell distribution width, PCT: Plateletcrit, NRBC: Nucleated red blood cell
\end{tabular}

In order to find cut-off values for RDW and NRBC to predict GDM, ROC curve analysis was performed. A RDW of 13.75 was found to predict GDM with a sensitivity of $60 \%$ and a specificity of $62.6 \%$ (Figure 1). For NRBC 0.005 was found to have a sensitivity of $32.5 \%$ and a specificity of $85.5 \%$ for GDM prediction (Figure 2). NRBC was found to be positive $(>0)$ in $30.9 \%$ ( $\mathrm{n}: 25 / 81$ ) of the patients with GDM and only $14.4 \%$ of the patients without GDM (chi square, p:0.001).

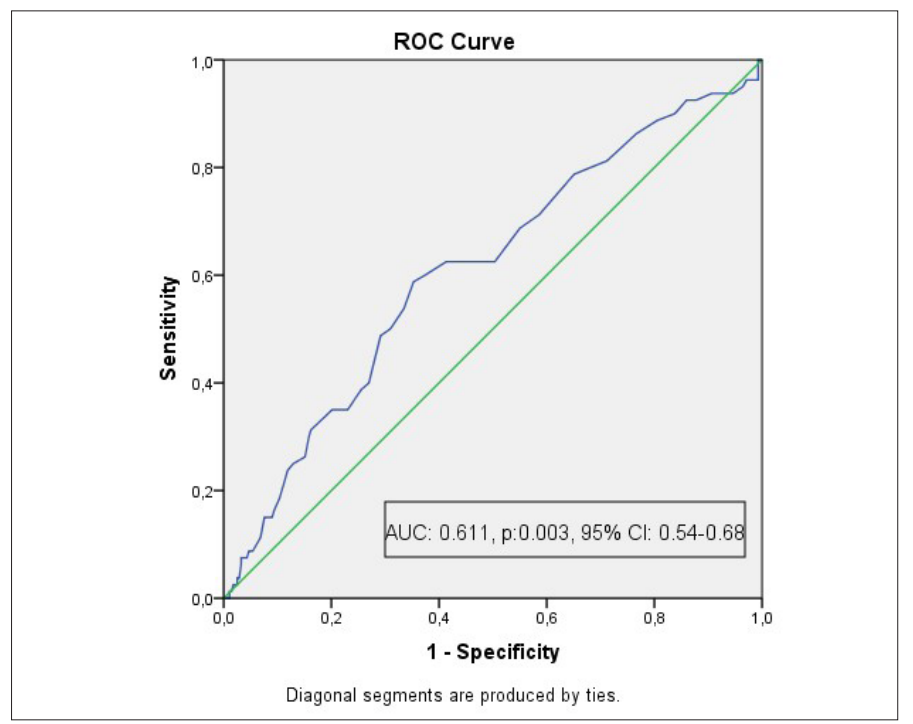

Figure 1. ROC curve analysis for red cell distribution width for gestational diabetes diagnosis

AUC: Area under the curve, $\mathrm{Cl}$ : Confidence interval 


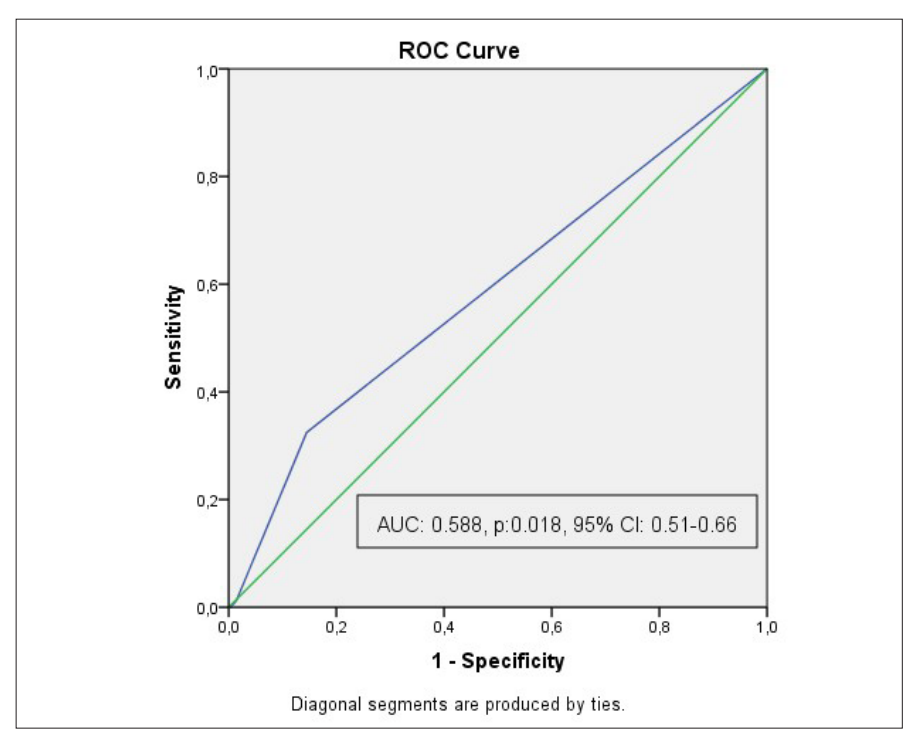

Figure 2. ROC curve analysis for nucleated red blood cell for gestational diabetes diagnosis.

AUC: Area under the curve, $\mathrm{Cl}$ : Confidence interval

\section{DISCUSSION}

$\mathrm{CBC}$ is a simple, inexpensive and widely available test that provides very important data with regard to many diseases. In this study it was shown that this test also has a potential to provide clues for GDM diagnosis. RDW and NRBC, but not platelet indices, seem to have a predictive role. These findings suggest women with GDM may be accompanied with increased RDW and NRBC levels which seem to be independent predictors of this disease and these parameters may be used to monitor and evaluate the development of GDM.

GDM has been shown to be a chronic inflammatory condition that is one of the key components of the pathogenesis of insulin resistance and type 2 diabetes with increased proinflammatory cytokines. ${ }^{[2,6,21]}$ This subclinical inflammation affects hematological parameters including platelets, white blood cells and red blood cells. Platelet hyperactivity has been reported in diabetes both in vivo and in vitro. ${ }^{[22]}$ Platelet indices including MPV, PDW, PCT and indices such as PLR and NLR have been shown to be affected in GDM patients. ${ }^{[8-12]}$ However, the results are contradictory as there are numerous studies that reported no difference in these parameters. ${ }^{[10,14-17]}$ Similarly, there are contradictory results with respect to WBC and red blood cells. ${ }^{[13,16]}$ Among platelet indices only PCT was found to be increased significantly in GDM patients; however, in regression analysis this association disappeared indicating that PCT is not an independently associated factor. PMI was also assessed which had not been assessed in GDM before. PMI has been suggested to be a better parameter of inflammation than MPV. ${ }^{[23]}$ Again, no association was observed between PMI and GDM. Similarly, no significant difference was observed in the levels of total WBC and its subtypes including neutrophils and lymphocytes. Immature granulocytes were also assessed for the first time in GDM. Immature granulocytes had been shown to be increased in inflammatory states much earlier than conventional parameters. ${ }^{[24,25]}$ No significant difference was observed in this parameter in GDM patients and controls. The possible mechanism may be that GDM is a subclinical inflammatory state and IG and PMI are associated with more clinically prominent inflammatory states. From this point the platelet indices, NLR, PLR and immature granulocytes do not seem to have a predictive value for GDM diagnosis.

RDW is a hematologic parameter that reflects anisocytosis and is expressed as the ratio between the standard deviation of RBC volumes and the mean corpuscular volume multiplied by 100 . Recently it has been shown to reflect the systemic inflammatory states and has been associated with the severity and prognosis in several diseases including diabetes. ${ }^{[26]}$ Anisocytosis was reported to be more prevalent in GDM. ${ }^{[27]}$ In their cohort study including 16971 adults Wang et al found that each unit increase of RDW was associated with a $16 \%$ higher incident diabetes and concluded that high RDW was associated with high risk of diabetes. ${ }^{[25]}$ The number of studies assessing the association between RDW and GDM is scarce and there are conflicting results. Erdogan et al retrospectively investigated 68 patients with GDM and 61 health controls. [15,28,29] They found no difference between RDW levels; however, Yildiz et al reported significantly increased RDW values in GDM patients. ${ }^{[28]}$ Similarly, Cheng et al found RDW to be an independent predictor of early stage renal injury in GDM patients. ${ }^{[29]}$ In the present study we showed significantly increased RDW in GDM patients and in regression analysis RDW came out to be an independent predictor of GDM. Our study included 359 pregnant women and had a larger sample size than the aforementioned studies. The possible mechanism of the increase of RDW in GDM could be explained by several pathways. Hypergylcemia and oxidative stress lead structural changes in RBC and effects lifespan of RBCs

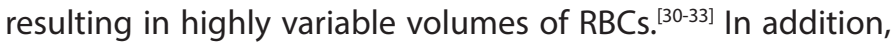
due to proinflammatory cytokines synthesis of erythropoietin is disturbed which results in a gradual increase in RDW values. ${ }^{[34,35]}$ A RDW value of $\geq 13.75$ of our laboratory was found to predict GDM with relatively low sensitivity and specificity with an area under the curve value of 0.611 in the ROC analysis. Based on the contractual classification system, the surface below the ROC curve in the range of $0.7-0.8$ is not a strong predictor of clinical sensitivity or specificity. ${ }^{[36]}$ Moreover, it must be kept in mind while interpreting this data is that as a technical issue in routine assessment of RDW, the reference range is highly analyser-dependent. ${ }^{[37]}$ Our cut-off value is based on our laboratory findings.

NRBC are immature erythrocytes, produced in response to increased erythropoietin which is secreted in cases of tissue hypoxia. ${ }^{[28,29]}$ In infants there are studies that show elevated NRBC count in relation with complications like hypoxia, ${ }^{[40]}$ hypoxemia, ${ }^{[41]}$ asphyxia, maternal diabetes, prenatal brain damage, preterm infants, ${ }^{[18]} \mathrm{RDS}_{,}{ }^{[42]}$ and preeclampsia. ${ }^{[43]}$ Vatansever et al. ${ }^{[18]}$ demonstrated that serum erythropoietin concentrations were high in intrauterine growth restricted 
infants and infants of diabetic mothers. However, there are no studies that assess the significance of NRBC in maternal circulation with respect to pregnancy complications. In this study we showed for the first time that NRBC of GDM patients increases significantly and NRBC may function as a diagnostic parameter for GDM. It was found to be independently associated factor with a relatively high specificity, but low sensitivity when a cut-off value was set at 0.005 . As stated, GDM is an inflammatory state with altered erythropoietin secretion and hyperglycemia with oxidative stress may result in some degree of hypoxia for the mother. This relative hypoxic state may result with increased circulation of NRBC. However, NRBC count has a variable pattern and this must be regarded while interpreting our findings.

The main strength of the present study is that NRBC, PMI and immature granulocytes have been assessed for the first time in the GDM. All the patients were from the same clinic and all the blood analysis had been performed with the same devices which provides standardization. The retrospective design was the main drawback. And one should keep in mind while interpreting these data is that the assessed parameters are highly analyzer-dependent and variable. Therefore, prospective, single or multicenter studies that use the same analyzers with larger sample sizes would be more informative.

\section{CONCLUSION}

A simple CBC test in the 24-28 weeks of gestation seem to have informative data with respect to GDM development. Neither of the platelet indices including PMI and MPV nor white blood cell subtypes including immature granulocytes have diagnostic role for GDM. However, RDW and NRBC significantly increase in GDM patients and although laboratory and analyzer dependent and have variable serum patterns, increased RDW and NRBC levels may be useful in the assessment of patients who have increased risk for GDM.

\section{ETHICAL DECLARATIONS}

Ethics Committee Approval: Ethical Approval was obtained from Mersin University's Ethical Committee. (8/07/2020, 14/495)

Informed Consent: Because the study was designed retrospectively, no written informed consent form was obtained from patients.

Referee Evaluation Process: Externally peer-reviewed.

Conflict of Interest Statement: The authors have no conflicts of interest to declare.

Financial Disclosure: The authors declared that this study has received no financial support.

Author Contributions: All of the authors declare that they have all participated in the design, execution, and analysis of the paper, and that they have approved the final version.

\section{REFERENCES}

1. Gabbe S, Niebyl J, Simpson J, Landon M, Galan H, Jauniaux E, Driscoll D, Berghella V, Grobman W. Obstetrics: Normal and Problem Pregnancies. Diabetes Mellitus Complicating Pregnancy. 7th ed. Elsevier, 2016.

2. Lekva T, Norwitz ER, Aukrust P, Ueland T. Impact of systemic inflammation on the progression of gestational diabetes mellitus. Curr Diab Rep 2016;16(4):26

3. ACOG Practice Bulletin No. 190 Summary: Gestational Diabetes Mellitus. Obstet Gynecol 2018:131(2):406-8.

4. Moyer VA. Screening for gestational diabetes mellitus: U.S. Preventive Services Task Force recommendation statement. U.S. Preventive Services Task Force. Ann Intern Med 2014;160:414-20.

5. Classification and diagnosis of diabetes. American Diabetes Association Diabetes Care 2017;40:S11-24.

6. Hernandez TL, Van Pelt RE, Anderson MA, et al. Women with gestational diabetes mellitus randomized to a higher-complex carbohydrate/lowfat diet manifest lower adipose tissue insulin resistance, inflammation, glucose, and free fatty acids: a pilot study. Diabetes Care 2016;39(1):39-42.

7. Santilli F, Vazzana N, Liani R, Guagnano MT, Davì G. Platelet activation in obesity and metabolic syndrome. Obes Rev 2012;13(1):27-42.

8. Sefil F, Ulutas KT, Dokuyucu R, et al. Investigation of neutrophil lymphocyte ratio and blood glucose regulation in patients with type 2 diabetes mellitus. J Int Med Res 2014;42(2):581-8.

9. Yilmaz H, Celik HT, Namuslu M, et al. Benefits of the neutrophil-tolymphocyte ratio for the prediction of gestational diabetes mellitus in pregnant women. Exp Clin Endocrinol Diabetes 2014;122(1):39-43.

10. Sargin MA, Yassa M, Taymur BD, Celek A, Ergun E, Tug N. Neutrophilto-lymphocyte and platelet-to- lymphocyte ratios: are they useful for predicting gestational diabetes mellitus during pregnancy? Ther Clin Risk Manag 2016:657-66.

11. Fashami MA, Hajian S, Afrakhteh M, Khoob MK. Is there an association between platelet and blood inflammatory indices and the risk of gestational diabetes mellitus? Obstet Gynecol Sci 2020;63(2):133-40.

12. Zhou Z, Chen H, Sun M, Ju H. Mean platelet volume and gestational diabetes mellitus: a systematic review and meta-analysis. J Diabetes Res 2018;2018:1985026.

13. Yang H, Zhu C, Ma Q, Long Y, Cheng Z. Variations of blood cells in prediction of gestational diabetes mellitus. J Perinat Med 2015;43:89-93.

14. Chen $X$, Fang $L$, Lin $H$, et al. The relationship between type 2 diabetes and platelet indicators. Iran J Public Health 2017;46:1211-6.

15. Erdoğan S, Ozdemir O, Doğan HO, et al. Liver enzymes, mean platelet volume, and red cell distribution width in gestational diabetes. Turk J Med Sci 2014;44:121-5.

16. Mertoglu C, Gunay M Gungor M, Kulhan M, Kulhan NG. A study of inflammatory markers in gestational diabetes mellitus. Gynecology Obstetrics \& Reproductive Medicine 2019;25(1):7-11

17. Gorar S, Abanonu GB, Uysal A, et al. Comparison of thyroid function tests and blood count in pregnant women with versus without gestational diabetes mellitus. J Obstet Gynaecol Res 2017;43:848-54.

18. Vatansever U, Acunaş B, Demir M, et al. Nucleated red blood cell counts and erythropoietin levels in high-risk neonates. Pediatr Int 2002;44:590-5

19. Nada AM. Red cell distribution width in type 2 diabetic patients. Diabetes Metab Syndr Obes 2015;8:525-33.

20. Metzger BE, Gabbe SG, Persson B, et al. International association of diabetes and pregnancy study groups recommendations on the diagnosis and classification of hyperglycemia in pregnancy. International association of diabetes and pregnancy study groups consensus panel. Diabetes Care 2010;33:676-82.

21. Mertoglu C, Gunay M. Neutrophil-Lymphocyte ratio and PlateletLymphocyte ratio as useful predictive markers of prediabetes and diabetes mellitus. Diabetes Metab Syndr 2017;11(Suppl 1):S127-S131 
22. Bae SH, Lee J, Roh KH, Kim J. Platelet activation in patients with diabetic retinopathy. Korean J Ophthalmol 2003;17(2):140-4.

23. Okur N, Buyuktiryaki M, Uras N, et al. Platelet mass index in very preterm infants: can it be used as a parameter for neonatal morbidities? J Matern Fetal Neonatal Med 2016;29:3218-22.

24. Unal Y, Barlas AM. Role of increased immature granulocyte percentage in the early prediction of acute necrotizing pancreatitis Ulus Travma Acil Cerrahi Derg, 2019;25:177-82.

25. Karakulak S, Narcı H, Ayrık C, Erdoğan S, Üçbilek E. The prognostic value of immature granulocyte in patients with acute pancreatitis. Am J Emerg Med 2020;S0735-6757(20)30170-4.

26. Wang J, Zhang Y, Wan Y, Fan Z, Xu R. The relationship between red blood cell distribution width and incident diabetes in chinese adults: a cohort study. J Diabetes Res 2020;2020:1623247.

27. Rajab AM, Rahman S, Rajab TM, Haider KH. Morphology and Chromic Status of Red Blood Cells Are Significantly Influenced by Gestational Diabetes. J Hematol. 2018;7(4):140-8.

28. Yildiz S, Üçler R, Alay M, Ekici EB. Which hemogram parameter is more cautionary in euthyroid patients with gestational diabetes mellitus. East J Med 2016;21:162-7.

29. Cheng D, Zhao J, Jian L, Ding T, Liu S. Relationship between red cell distribution width and early renal injury in patients with gestational diabetes mellitus. Ren Fail 2016;38:1218-23.

30. Symeonidis A, Athanassiou G, Psiroyannis A, et al. Impairment of erythrocyte viscoelasticity is correlated with levels of glycosylated haemoglobin in diabetic patients. Clinical and Laboratory Haematology 2001;23(2):103-9.

31. Livshits L, Srulevich A, Raz I, et al. Effect of short-term hyperglycemia on protein kinase $C$ alpha activation in human erythrocytes. The Review of Diabetic Studies 2012;9(2-3):94-103.

32. Panzer S, Graninger W, Kronik G, Bettelheim P, Lechner K. Glycosylated hemoglobin as a long-term parameter in appraising the severity of hemolytic disease. Klinische Wochenschrift. 1983;61(17):839-43.

33. Friedman JS, Lopez MF, Fleming MD., et al. SOD2-deficiency anemia: protein oxidation and altered protein expression reveal targets of damage, stress response, and antioxidant responsiveness. Blood 2004;104(8):2565-73.

34. Kario K, Matsuo T, Nakao K, Yamaguchi N. The correlation between red cell distribution width and serum erythropoietin titres. Clinical and Laboratory Haematology 1991;13(2):222-3.

35. Afsar B, Saglam M, Yuceturk C, Agca E. The relationship between red cell distribution width with erythropoietin resistance in iron replete hemodialysis patients. European Journal of Internal Medicine 2013;24(3):e25-e29.

36. Akobeng AK. Understanding diagnostic tests 3: receiver operating characteristic curves. Acta Paediatr 2007;96:644-7.

37. Durnwald C. Diabetes mellitus in pregnancy: screening and diagnosis [Internet] Waltham (MA): UpToDate;2018. [Accessed 2018 Aug 4]. Available from: https://www.uptodate.com/contents/diabetes-mellitusin-pregnancy-screening-and-diagnosis.

38. Phelan JP, Ahn MO, Korst LM, Martin Gl. Nucleated red blood cells: a marker for fetal asphyxia. Am J Obstet Gynecol 1995;173:1380-4.

39. Maier RF, Böhme K, Dudenhausen JW, Obladen M. Cord blood erythropoietin in relation to different markers of fetal hypoxia. Obstet Gynecol 1993;81:575-80.

40. Saraçoglu F, Sahin I, Eser E, Göl K, Türkkani B. Nucleated red blood cells as a marker in acute and chronic fetal asphyxia. Int J Gynaecol Obstet 2000;71:113-8.

41. Axt-Fliedner R, Ertan K, Hendrik HJ, Schmidt W. Neonatal nucleated red blood cell counts: relationship to abnormal fetoplacental circulation detected by Doppler studies. J Ultrasound Med 2001;20:183-90.
42. Baschat AA, Gembruch U, Reiss I, Gortner L, Harman CR. Neonatal nucleated red blood cell count and postpartum complications in growth restricted fetuses. J Perinat Med 2003;31:323-9.

43. Bayram F, Ozerkan K, Cengiz C, Develioğlu O, Cetinkaya M. Perinatal asphyxia is associated with the umbilical cord nucleated red blood cell count in preeclamptic pregnancies. J Obstet Gynaecol 2010;30:383-6. 